\title{
Petroleum Hydrocarbon Utilization by Some Molecularly Identified Filamentous Marine Fungi Isolated from a Polluted Area in the Mediterranean Sea
}

\author{
${ }^{\mathbf{1}}$ Eman A. H. Mohamed ${ }^{\mathbf{1}}$ and Hala Y. El-Kassas * \\ Department of Botany, Faculty of Science, Alexandria University, \\ Damanhour Branch and *Hydrobiology Laboratory, Marine \\ Environmental Division, National Institute of Oceanography and \\ Fisheries, Alexandria, Egypt.
}

\begin{abstract}
7 HREE DIFFERENT newly isolated marine fungi were subjected to $18 \mathrm{~S}$ rRNA gene partial sequence analysis. The resulting sequences showed that the isolates belong to Fusarium solani, Trichoderma viride and Aspergillus niger. The isolates have the ability to utilize some petroleum hydrocarbons such as hexane, motor oil and diesel oil. The tested fungi could grow up to 7 days, especially on medium supported with diesel oil. Although all of the tested fungi have the ability to utilize the increased concentrations of diesel oil, Fusarium solani $\mathrm{EH}$ has the highest ability, growing at a concentration of $4 \mathrm{ml} / \mathrm{l}$. Static and shaking incubation conditions of Fusarium solani $\mathrm{EH}$ with $7.2 \mathrm{mg} / 100 \mathrm{ml}$ diesel oil as a sole carbon source, showed significant decrease in the hydrocarbon concentration (90.28\% and $93.05 \%$, respectively) within 7 days. Results of this study may provide a help in petroleum hydrocarbon spill clean-up.
\end{abstract}

Keywords: Marine, Fungi, 18S rDNA, Diesel oil.

Petroleum is a complex mixture of molecules called hydrocarbons. At high concentrations, hydrocarbon molecules are highly toxic to marine organisms, including diatoms, gastropods, mussels, crustaceans and fishes (Adekunle \& Adebambo, 2007). These contaminants ultimately pose a serious threat to human health (Alexander, 1994 and Raghukumar et al., 2006). Biodegradation of hydrocarbon by natural populations of microorganisms represents one of the primary mechanisms by which petroleum and other hydrocarbon pollutants are eliminated from the environment (Leahy \& Colwell, 1990). However, fungi have been found to be better degraders of petroleum than traditional bioremediation techniques including bacteria (Batelle, 2000).

Marine fungi is a collective term for a large group of fungi which are saprophytes or parasites in the marine environment (Hyde, 1989). Some marine fungi are able to grow using hydrocarbons as their sole source of organic carbon. Therefore, they are not only sources of nutrients in marine food webs, but also 
potential participants in degradation of spilled petroleum (Cooney et al., 1993). Floodgate (1984) has listed 27 genera of hydrocarbon-degrading fungi which have been isolated from the marine environment. Based on the published reports, the most important hydrocarbon-degrading/utilizing fungi from marine habitats are Aureobasidium, Candida, Rhodotorula and Sporobolomy spp. On the other hand, Trichoderma and Mortierella spp. are the most common soil isolates. Hydrocarbon-degrading Aspergillus and Penicillium spp. have been frequently isolated from both environments (Leahy \& Colwell, 1990). Raghukumar et al. (2006) have isolated a marine fungus, Flavodon flavus NIOCC \# 312, that has great potential in pollution clean-up, especially for the removal of polycyclic aromatic hydrocarbons. Although mixed fungal cultures were used for hydrocarbon removal, Okerentugba \& Ezeronye (2003) demonstrated that Penicillium, Aspergillus and Rhizopus spp. were able to degrade hydrocarbons, especially when single cultures were used.

Conventional laboratory identification of fungi often relies on a variety of morphological and physiological tests. This process is tedious and time consuming (Fell, 1993; Sandhu et al., 1995; Kappe et al., 1996; Shin et al., 1997 and Kim et al., 1999). On the other hand, PCR (Polymerase Chain Reaction) is a rapid and sensitive technique for specific amplification of a particular segment of DNA. As in other cells, ribosomal RNA (rRNA) genes in microbial cells are both highly conserved and present in multiple copies. Therefore, they are popular targets for gene amplification and molecular analysis (Lee \& Taylor, 1990; Lewin, 1990; Sandhu et al., 1995 and Einsele et al., 1997).

In this research, three newly isolated marine fungi which are capable of utilization of some hydrocarbons as sole carbon sources were successfully identified using fungi-specific primer pair (FF2/FR1) (Zhou et al., 2000). The primer pair was used to amplify and molecularly characterize approximately 400 bp of the $18 \mathrm{~S}$ rRNA gene.

\section{Material and Methods}

\section{Marine fungi isolation and maintenance}

Sea water samples were collected from a hydrocarbon-polluted area in the Mediterranean Sea, El- Max, Alexandria, Egypt, during spring 2009. Marine fungi were isolated from collected samples in a solidified medium according to Cooke (1963), with a slight modification (using sea water instead of dist. water). The medium composition (g/l) is: glucose 10, peptone 5, Rose Bengal 0.033 and agar 15. Medium components were then dissolved in one liter of sea water and sterilized at $121^{\circ} \mathrm{C}$ for $15 \mathrm{~min}$. After pouring and solidification in Petri-dishes, the plates were inoculated with $1 \mathrm{ml}$ of the diluted samples, by spreading over the medium surface. Fungal cultures were incubated at $28{ }^{\circ} \mathrm{C}$ for 5 days. Colonies were then picked up, purified and maintained in malt extract agar medium.

Egypt. J. Microbiol. 45 (2010) 


\section{Hydrocarbon utilization}

Hydrocarbon utilization screening plates were composed of mineral salt medium (MSM) proposed by Cunha et al. (2001), supplemented with 0.24, 0.4, $0.8,1.6,2.4,3.3$ or $4 \%(\mathrm{v} / \mathrm{v})$ petroleum derivative as a sole carbon source (hexane, diesel or motor oil), in addition to $0.5 \%$ glucose for growth enhancement. The MSM composition in $\mathrm{g} / \mathrm{l}$ is: $\mathrm{KH}_{2} \mathrm{PO}_{4} 0.4, \mathrm{MgSO} 4.7 \mathrm{H}_{2} \mathrm{O} 0.2$, $\mathrm{NaCl} 0.1, \mathrm{CaCl}_{2} .2 \mathrm{H}_{2} \mathrm{O} 0.025, \mathrm{MnSO}_{4} \cdot \mathrm{H}_{2} \mathrm{O} 0.003, \mathrm{NH}_{4} \mathrm{NO}_{3} .2 \mathrm{H}_{2} \mathrm{O} 0.5$ and agar 15. The isolated fungi were used to centrally inoculate the surface of Petri plates $(5 \mathrm{~mm})$ containing hydrocarbon-based MSM. Three replicates were used for each fungus with a certain concentration of a sole hydrocarbon source. The plates were incubated for 7 days at $28^{\circ} \mathrm{C}$ and examined periodically for changes in colony diameter.

For measuring of the total hydrocarbons, mycelia were allowed to grow in diesel oil containing liquid MSM under shaking and static conditions for 7 days at $28^{\circ} \mathrm{C}$. Cultures were then centrifuged and supernatants were treated according to Parsons et al. (1984). Total hydrocarbons were quantified using Flurometer 450, USA.

Standard deviations for colony diameter values were obtained using SPSS program.

\section{Electron transmission microscopy (ETM)}

For fungal examination by ETM, mycelia were dehydrated serially throughout increased alcohol concentrations and treated by standard procedures (Reynolds, 1963). Finally, samples were scanned by ETM (JEOL 100CX, Japan) at the Electron Microscope Unit- Faculty of Science- Alexandria University.

DNA extraction, purification and amplification

$200 \mathrm{mg}$ of fungal mycelia were collected and vigorously squashed. DNA was extracted and purified using EZNA Fungal DNA kit, Omega Bio-Tek. Approximately $400 \mathrm{bp}$ of the fungal $18 \mathrm{~S}$ rRNA gene were amplified using a fungal-specific primer pair FF2/FR1 (Zhou et al., 2000). The forward primer FF2 is: 5'- GGTTCTATTTTGTTGGTTTCTA-3', and the reverse is: 5'CTCTCAATCTGTCAATCCTTATT-3'. Two $\mu \mathrm{l}(100 \mathrm{ng})$ of DNA were amplified with each primer $(10 \mathrm{pmol})$ and $2 \mathrm{X}$ PCR Master Mix, ready- to - use PCR mixture containing $0.05 \mathrm{U} / \mu 1$ Taq polymerase, PCR buffer, $4 \mathrm{mM} \mathrm{MgCl} \mathrm{Mg}_{2}$ and $0.4 \mathrm{mM}$ dNTPs (MBI Fermentas, Germany). The 50 $\mu 1$ PCR mixturecontaining tube was placed in the DNA thermocycler, Gene Cycler ${ }^{\mathrm{TM}}$ BIO-RAD, USA. The conditions for PCR were as follows: initial denaturation of DNA at $95^{\circ} \mathrm{C}$ for $3 \mathrm{~min}$ and then 35 cycles of three-step PCR amplifications consisting of denaturation at $94^{\circ} \mathrm{C}$ for $1 \mathrm{~min}$, primer reannealing at $52^{\circ} \mathrm{C}$ for $1 \mathrm{~min}$ and extension at $72^{\circ} \mathrm{C}$ for $2 \mathrm{~min}$. Samples were subjected to an additional extension at $72^{\circ} \mathrm{C}$ for $10 \mathrm{~min}$ at the end of the amplification cycles (Zhou et al., 2000). 


\section{Gel electrophoresis}

Ten $\mu 1$ of PCR products, mixed with loading buffer, were loaded on a $2 \%$ w/v agarose gel and electrophoresed with $1 \mathrm{X}$ TEA (Tris EDTA Acetate) buffer. DNA was visualized by UV transillumination after staining with ethidium bromide $(0.5 \mu \mathrm{g} / \mathrm{ml})$. The molecular sizes of the amplified DNA fragments were estimated using DNA ladder of $100 \mathrm{bp}$.

DNA sequencing

PCR products were purified to remove excess primers using QIA quick PCR purification reagents (Qiagen, USA) and then sequenced with the BigDye Terminater cycle sequencing kit (Applied Biosystems, USA) in ABI Prism 3730 sequencer (Perkin Elmer, Applied Biosystem, USA). Sequences were deposited in the GenBank and the accession numbers are listed in Table 5.

Data analysis and construction of the phylogenetic tree

After obtaining the sequences, homology search was performed against DDBJ (DNA Data Base Japan), using Blast program to find the sequences producing significant alignment with the obtained sequences. Similarity percentages among the sequences were obtained using Biology WorkBench software version 3.2. Multisequence alignment and molecular phylogeny were performed using ClustalW (a distance-based analysis program at DDBJ) program. The tree topology was evaluated using the neighbor-joining method (Saitou \& Nei, 1987) based on 1000 resamplings.

\section{Results}

Three marine fungi were isolated recently from a hydrocarbon-polluted sea spot in the Mediterranean Sea and they are as follows: Aspergillus niger $\mathrm{EH}$, Trichoderma viride $\mathrm{EH}$ and Fusarium solani $\mathrm{EH}$. The growth of each fungus on the mineral salt medium (MSM) containing one hydrocarbon $(0.24 \mathrm{v} / \mathrm{v})$ as a sole carbon source was generally screened in Table 1 . It shows that all of the isolates can utilize diesel oil as an organic carbon source. Motor oil cannot be utilized properly by them. Only Fusarium and Trichoderma showed promising growth in a MSM containing hexane. However, growth was found to be more vigorous in case of Fusarium grown on diesel oil. Accordingly, diesel oil was subjected to more study throughout different time intervals at a concentration of $0.24(\mathrm{v} / \mathrm{v})$, using the three isolates. Data in Table 2 shows that diesel oil is utilized increasingly with time as indicated by colony diameter. After 7 days of incubation, the maximum colony diameter was detected for each fungus, especially for Fusarium colonies which reached a diameter of approximately $20 \mathrm{~mm}$. There is almost no growth after 7 days of incubation.

Egypt. J. Microbiol. 45 (2010) 
TABLE 1. General screening for some hydrocarbon utilization by the isolated fungi after 7 days of incubation at $28^{\circ} \mathrm{C}$.

\begin{tabular}{|l|c|c|c|}
\hline \multirow{2}{*}{\multicolumn{1}{|c|}{ Fungi }} & \multicolumn{3}{c|}{ Hydrocarbon (0.24\% v/v) } \\
\cline { 2 - 4 } & Motor oil & Hexane & Diesel oil \\
\hline Fusarium solani & - & + & ++ \\
\hline Trichoderma viride & - & + & + \\
\hline Aspergillus niger & - & - & + \\
\hline
\end{tabular}

++, heavy growth; +, moderate growth and -, weak growth

TABLE 2. Average colony diameters $(\mathrm{mm}) \pm$ standard deviations for growth on diesel oil $(0.24 \% \mathrm{v} / \mathrm{v})$ during different incubation periods.

\begin{tabular}{|c|c|c|c|}
\hline \multirow{2}{*}{ Fungi } & \multicolumn{3}{|c|}{ Time (days) } \\
\cline { 2 - 4 } & $\mathbf{2}$ & $\mathbf{4}$ & $\mathbf{7}$ \\
\hline Fusarium solani & $13 \pm 0.36$ & $16 \pm 0.25$ & $20 \pm 0.25$ \\
\hline Trichoderma viride & $11 \pm 0.32$ & $13 \pm 0.35$ & $18 \pm 0.21$ \\
\hline Aspergillus niger & $10 \pm 0.35$ & $13 \pm 0.31$ & $18 \pm 0.22$ \\
\hline
\end{tabular}

- No diesel oil or alternate carbon source.

Within a fixed time, 7 days, diesel oil utilization starting from an elevated levels of its concentration $(0.4-4 \mathrm{v} / \mathrm{v})$ was detected for each fungus (Table 3). Generally, colony diameter increased in parallel with the elevated diesel oil levels. Fusarium, Trichoderma and Aspergillus, respectively showed the most vigorous growth at a concentration of $4 \%(\mathrm{v} / \mathrm{v})$ of diesel oil. Again, the maximum colony diameter, $35 \mathrm{~mm}$, was obtained in case of Fusarium. Accordingly, Fusarium was selected for further analysis to measure the total hydrocarbon content remaining after 7 days of shaking and stagnant conditions in the presence of diesel oil- containing MSM. Results in Table 4 show that around $90.28 \%$ of the diesel oil was utilized by Fusarium under static incubation and about $93.05 \%$ were utilized under shaking. Controls with no fungus showed almost no diesel loss by evaporation within 7 days.

TABLE 3. Colony diameter (mm) of Fusarium, Trichoderma and Aspergillus grown on different concentrations of diesel oil after 7 days .

\begin{tabular}{|c|c|c|c|c|c|c|c|}
\hline \multirow{2}{*}{ Fungi } & \multicolumn{7}{|c|}{ Diesel oil concentrations \% (v/v) } \\
\cline { 2 - 8 } & $\mathbf{0 . 0} *$ & $\mathbf{0 . 4}$ & $\mathbf{0 . 8}$ & $\mathbf{1 . 6}$ & $\mathbf{2 . 4}$ & $\mathbf{3 . 3}$ & $\mathbf{4}$ \\
\hline $\begin{array}{c}\text { Fusarium } \\
\text { solani }\end{array}$ & $2.2 \pm 0.04$ & $22 \pm 0.22$ & $26 \pm 0.17$ & $29 \pm 0.25$ & $32 \pm 0.24$ & $34 \pm 0.18$ & $35 \pm 0.20$ \\
\hline $\begin{array}{c}\text { Trichoderma } \\
\text { viride }\end{array}$ & $2 \pm 0.03$ & $20 \pm 0.31$ & $24 \pm 0.18$ & $27 \pm 0.22$ & $29 \pm 0.32$ & $31 \pm 0.26$ & $31 \pm 0.35$ \\
\hline $\begin{array}{c}\text { Aspergillus } \\
\text { niger }\end{array}$ & $1.6 \pm 0.04$ & $21 \pm 0.24$ & $24 \pm 0.22$ & $27 \pm 0.32$ & $30 \pm 0.33$ & $32 \pm 0.22$ & $33 \pm 0.30$ \\
\hline
\end{tabular}


TABLE 4. Total hydrocarbon content remained after diesel oil utilization by Fusarium.

\begin{tabular}{|l|c|c|c|}
\hline \multicolumn{4}{|c|}{ Total hydrocarbon content (mg/100ml) } \\
\hline \multicolumn{1}{|c|}{ Incubation conditions } & Zero time (control) & $\mathbf{2 ~ d a y s ~}$ & $\mathbf{7}$ days \\
\hline Static & 7.2 & 3.6 & 0.7 \\
\hline Shaking & 7.2 & 3.3 & 0.5 \\
\hline Static, non- inoculated & 7.2 & 7.2 & 7.12 \\
\hline Shaking, non- inoculated & 7.2 & 7.2 & 7.13 \\
\hline
\end{tabular}

Fusarium from control and diesel cultures were examined using electron transmission microscopy (Fig. 1). Figures $1 \mathrm{~A}$ and 1B show normal conidial and hyphal cells with their cytoplasmic organelles, while growing in a malt extract medium. Fusarium cells still have the ability to divide in the presence of $4 \%$ (v/v) of diesel oil as a sole source of organic carbon (Fig.1C). Distortion of cell organelles, presence of large vacuoles and appearance of inclusions are obvious (Fig. 1D and 1E), when cells subjected to hydrocarbon stress.

A

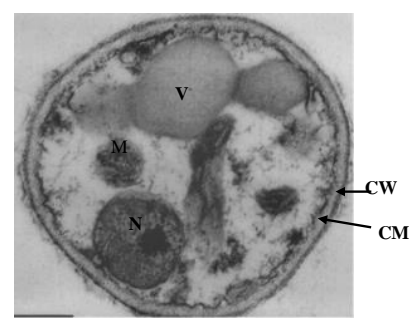

C

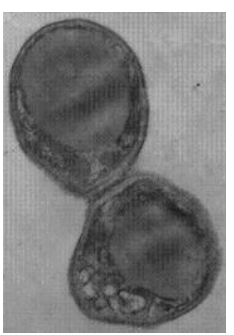

D

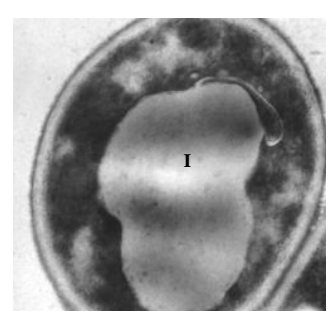

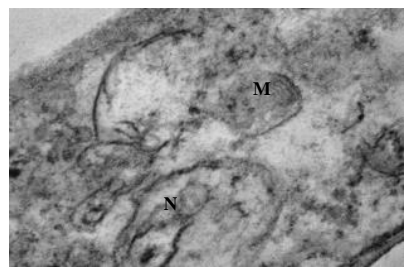

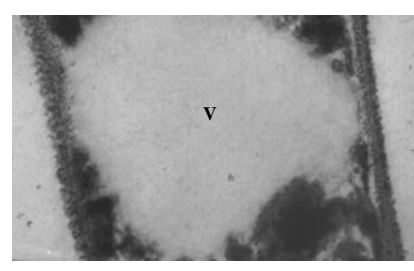

Fig. 1. Transmission Electron Microscopy of Fusarium solani growing in malt extract medium (A and B) and diesel oil containing mineral salt medium (C, $D$ and $E$ ). Conidia are shown in $A, C \& D$ and fungal hyphae are shown in B and $\mathrm{E}$. N, nucleus; $\mathrm{M}$, mitochondria; V, vacuole; I, inclusion; $\mathrm{CM}$, cell membrane and $\mathrm{CW}$, cell wall. 
Fungal specific primer pair, FF2/FR1 (Zhou et al., 2000), was used in this study to amplify around $400 \mathrm{bp}$ of the $18 \mathrm{~S}$ rRNA genes from the newly isolated fungi (Fig. 2). FF2 and FR1 were also used for partial sequencing of the $18 \mathrm{~S}$ rRNA gene. Most of the amplified DNA fragment has a highly conserved DNA sequences and the rest of it has a variable regions (Fig. 3). Accordingly, sequencing of this DNA fragment has proven useful for fungal identification (Zhou et al., 2000). The DNA sequences revealed that the isolated fungi are almost certainly Aspergillus niger, Fusarium solani and Trichoderma viride with similarity percentages of 100, 98 and 99, respectively. The sequences were deposited in the GenBank and accession numbers are given in Table 5. The phylogenetic analysis of the fungal sequences is summarized in Fig. 4. From the tree topology, it can be deduced that there are three fungal groups to which the new isolated strains belong. The Fusarium clade shows high homology with the target strain, F. solani EH, and F. solani strain E17084 (98\% similarity). Aspergillus clade exhibits strong homology between the present new strain, $A$. niger EH and A. niger strain contig An03c0110 (100\% similarity). Finally, the Trichoderma best matched $T$. viride strain RIB40 (99\% similarity).

TABLE 5. Accession numbers of the newly isolated fungal strains.

\begin{tabular}{|c|c|}
\hline Fungus & Accession number \\
\hline Aspergillus niger $\mathrm{EH}$ & GU733609 \\
\hline Fusarium solani $\mathrm{EH}$ & GU733608 \\
\hline Trichoderma viride $\mathrm{EH}$ & GU733610 \\
\hline
\end{tabular}

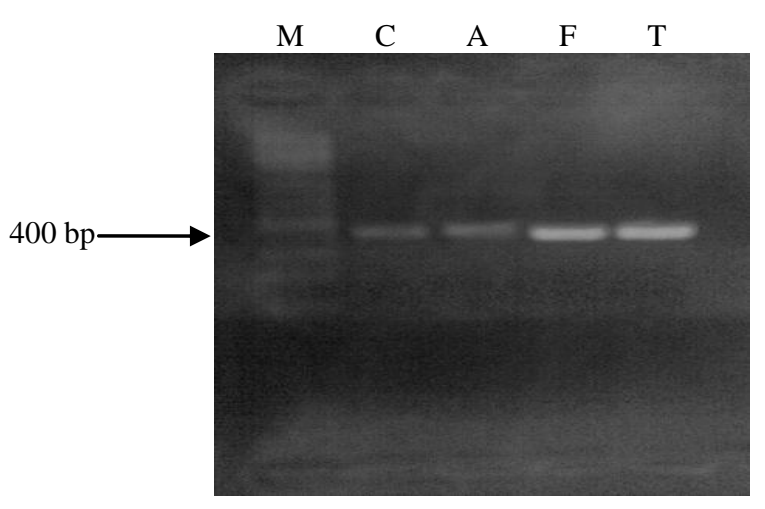

Fig. 2. Gel electrophoresis of approx. 400 bp of the $18 S$ rRNA gene. M, 100 bp genetic marker; C, control (Aspegillus niger ATCC 16404); A, Aspergillus niger EH; F, Fusarium solani $\mathbf{E H}$ and T, Trichoderma viride $\mathbf{E H}$.

Egypt. J. Microbiol. 45 (2010) 


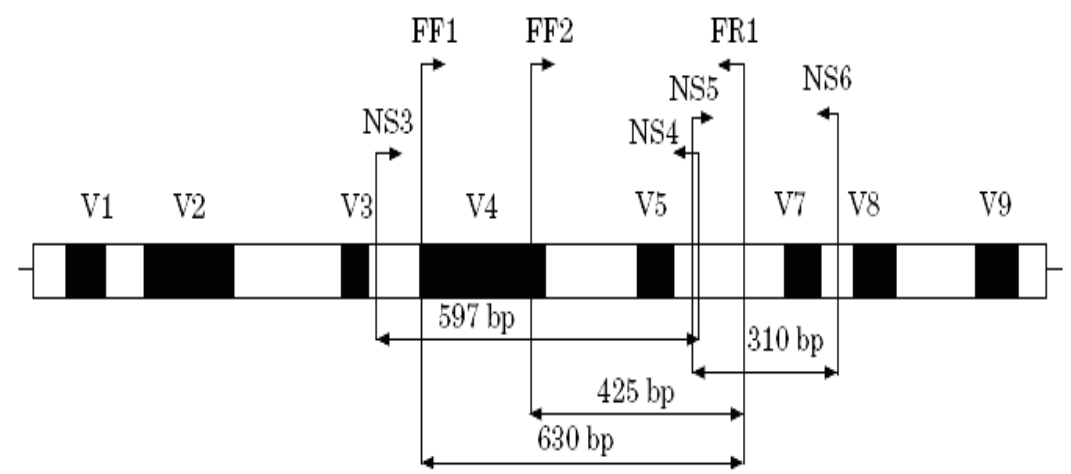

Fig. 3. Map of the 18S rRNA gene in fungi (adapted from Kappe et al., 1996) with highly conserved regions $(\square)$ and variable regions, V1 to V9 ( $\square$ ). The positions of primers and the sizes of amplified fragments are indicated.

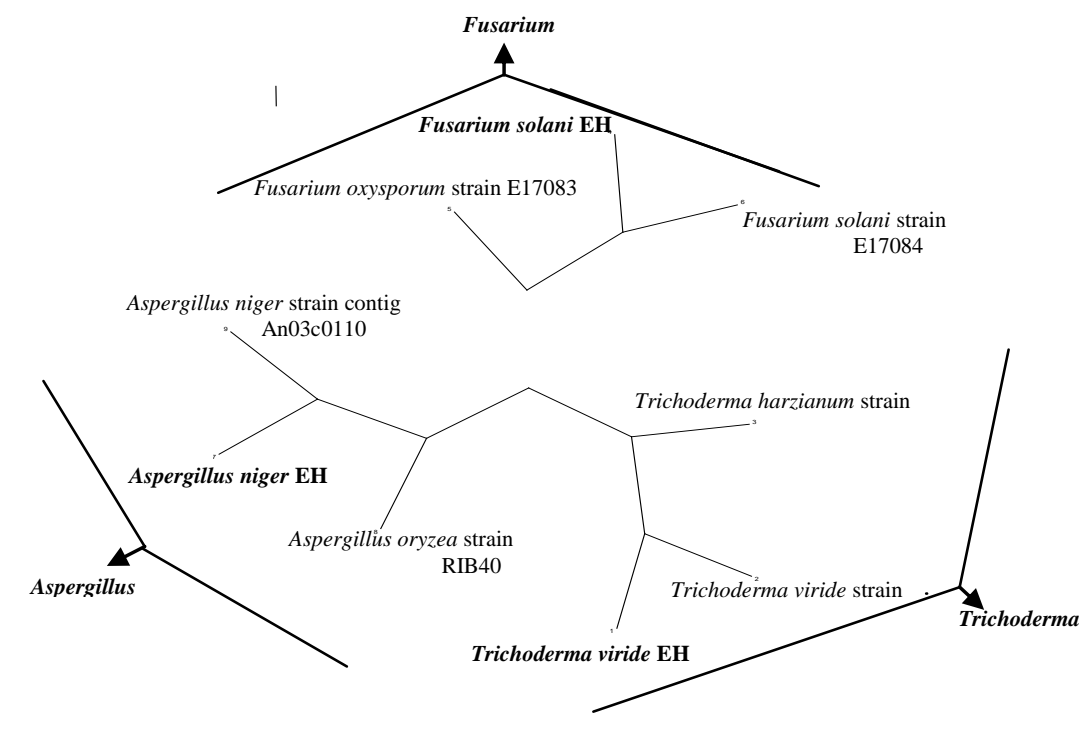

Fig. 4. Phylogenetic tree based on partial sequences (approx. $400 \mathrm{pb}$ ) of the fungal rRNA gene. The tree constructed by neighbor-joining method using ClustalW software.

Egypt. J. Microbiol. 45 (2010) 


\section{Discussion}

Results of the current research indicate that some marine fungi, namely $F$. solani, A. niger and $T$. viride are capable of degrading some petroleum hydrocarbons. Bartha \& Atlas (1997) listed 14 genera of fungi which had been demonstrated to contain members with the ability to utilize petroleum hydrocarbons. All of the 14 genera had been isolated from aquatic environment. Also, Okerentugba \& Ezeronye (2003) have demonstrated that Penicillium spp., Aspergillus spp. and Rhizopus spp. were capable of degrading hydrocarbons especially, when single cultures were used. Batelle (2000) showed that fungi were better degraders of hydrocarbons than bacteria. Results of the current work demonstrate that utilization of different hydrocarbons, namely, motor oil, hexane and diesel oil, varies among the isolated fungi. This may also account for the difference in growth rates among them Adekunle \& Adebambo, (2007). Colombo et al. (1996) who had studied hydrocarbon utilization by Aspergillus terreus, Penicillium chrysogenum and Fusarium solani, verified that the degradation capability varied according to the fungus. However, the fungi under study showed weak growth on motor oil, and Aspergillus exhibited significant growth (Table 1) in only one hydrocarbon, diesel oil. On the other hand, Fusarium was found to be the most promising among the tested isolates, especially when grown in diesel oil.

Petroleum-derived diesel is composed of about $75 \%$ saturated hydrocarbons (primarily paraffins including $\mathrm{n}$, iso, and cycloparaffins), and $25 \%$ aromatic hydrocarbons (including naphthalenes and alkylbenzenes) (ATSDR, 1995). An interesting observation generated in this study was that Fusarium has increased colony diameter with time upon using diesel oil as a sole organic carbon source, at least to a concentration of $4 \%(\mathrm{v} / \mathrm{v})$. Moreover, the total hydrocarbon content decreased $90.28 \%$ and $93.05 \%$ after 7 days of static and shaking incubation conditions, respectively. This fungus was able to use the hydrocarbon as a substrate for growth, presumably by releasing extra cellular enzymes and acids which are capable of breaking down the hydrocarbon molecules, thus dismantling the long chains of hydrogen and carbon into simpler forms that can be absorbed for growth and nutrition (Adekunle \& Adebambo, 2007). Previous studies have demonstrated utilization of many petroleum hydrocarbons by filamentous fungi (Santos et al., 2008 and Hadibarata \& Tachibana, 2009) and by Fusarium (Flippin et al., 1964; Michalcewicz, 1995; Yagafarova et al., 2001 and Chulalaksananukul et al., 2006).

The cell envelope of microorganisms basically consists of cell wall and 1 or 2 lipid membranes (Beveridge \& Graham, 1991). The cytoplasmic membrane has a low permeability for polar and charged molecules. Apolar compounds such as cyclic hydrocarbons, can easily penetrate the lipid bilayer. The transfer of such molecules across the membrane is most probably a diffusion process (Sikkema et al., 1995). Witholt et al. (1990) postulated that outer membrane lipopolysaccharides (LPS) are released and encapsulate hydrocarbon droplets. This may lead to the presence of inclusions (Fig. 1D) of unmodified hydrocarbons (Witholt et al., 1990). 
Besides, cell organelles are seriously affected by the presence of hydrocarbons (Sikkema et al., 1995), organelles distortion can be seen in Fig. 1D and 1E. For instance, cyclic hydrocarbons have serious effect on mitochondria, starting with the disappearance of the respiratory control and deenergization of the organelle, followed by respiration inhibition (Sikkema et al., 1995).

In contrast to phenotyping, which means classification based on the appearance or the reaction of the fungus, genotypic classification relies directly on analysis of DNA sequences. In general, the genotypic procedures are considered to be technically more complex, but the reproducibility and discriminatory power provides better results (Busch \& Nitschko, 1999). FF2/FR1 is a fungus-specific pair of PCR primers (Zhou et al., 2000) which was successfully used in this study to amplify approximately $400 \mathrm{bp}$ of the 18S rRNA genes. The phylogenetic analysis along with the similarity percentages, based on utilization of theses 18S rRNA gene partial sequences, revealed that the present isolated marine fungi are, or very closely related to A. niger, $T$. viride and $F$. solani (Fig. 3).

Acknowledgment: The authors are grateful to Mr. Mohamed M. El-Gendi, Botany Department- Faculty of Science- Alexandria University- Damanhour Branch, for his assistance and sincere cooperation.

\section{References}

Adekunle, A.A. and Adebambo, O. A. (2007) Petroleum hydrocarbon utilization by fungi isolated from Detarium senegalense (J. F. Gmelin) seeds. J. Am. Sci. 3(1), 6976.

Alexander, M. (1994) "Biodegradation and Bioremediation". Academic Press, New York, $692 \mathrm{pp}$.

ATSDR (1995) Agency for Toxic Substances and Disease Registry. Toxicological profile for fuel oils. Atlanta, GA: U.S. Department of Health and Human Services, Public Health Service.

Bartha, R. and Atlas, R.M. (1997) Biodegradation of oil in seawater, writing factor and artificial stimulation in: "The Microbial Degradation of Oil Pollutants", D.G. Ahern and S.P. Meyers (Ed.). pp. 147 - 152. Centre for Wetland Resources, Louissiana.

Batelle, C.D. (2000) Mushrooms: Higher macrofungi to clean up the environment. Batelle Environmental Issues, Fall 2000. (http://www.battelle.org/ Environment/ publications/ EnvUpdates/ Fall00/article4.html) .

Beveridge, T.J. and Graham, L.I. (1991) Surface layers of bacteria. Microbiol. Rev. 55, 684-705.

Busch, U. and Nitschko, H. (1999) Review in methods for the differentiation of microorganisms. J. Chrom. 722, 263-278.

Egypt. J. Microbiol. 45 (2010) 
Chulalaksananukul, S., Gadd, G.M., Sangvanich, P. and Sihanonth, P. (2006) Biodegradation of benzo(a)pyrene by a newly isolated Fusarium sp. FEMS Microbiol. Lett. 262, 99-106.

Colombo, J.C., Cabello, M. and Arambarri, A.M. (1996) Biodegradation of aliphatic and aromatic hydrocarbons by natural soil microflora and pure cultures of imperfect and lignolitic fungi. Environ. Pollut. 94, 355-362.

Cooke, W.B. (1963) A laboratory guide to fungi in polluted waters, sewage and sewage treatment systems: Their identification and culture. Cincinnati, Ohio: U.S.A. Department of Health, Education and welfare. p.132.

Cooney, J.J., Doolittle, M.M., Grahl-Nielsen, O., Haaland, I.M. and Kirk, P.W. (1993) Comparison of fatty acids of marine fungi using multivariate statistical analysis. J. Ind. Microbiol. 12, 373-378.

Cunha, C., Rosario, M., Rosario, A. and Leite, S. (2001) Screening of microorganisms with potential to produce biosurfactants in the presence of gasoline In: Proceedings of XXI Congress Brasileiro de Microbiologia held at Foz do Iguacu, Brazil, SBM, p.362.

Einsele, H., Hebart, H., Roller, G. and Loffler, J. (1997) Detection and identification of fungal pathogens in blood by using molecular probes. J. Clin. Microbiol. 35, 135360 .

Fell, J.W. (1993) Rapid identification of yeast species using three primers in a polymerase chain reaction. Mol. Mar. Biol. Biotech. 2, 174- 80 .

Flippin, R.S., Smith, C. and Mickelson, A.M.N. (1964) Fusarium growth supported by hydrocarbons. Appl. Microbiol.12(2), 93-95.

Floodgate, G. (1984) The fate of petroleum in marine ecosystems, p. 355-398. In: "Petroleum Microbiology". R. M. Atlas (Ed.), Macmillan Publishing Co., New York.

Hadibarata, T. and Tachibana, S. (2009) Microbial degradation of crude oil by fungi pre-grown on wood meal. Interdisciplinary studies on environmental chemistry: environmental research in Asia. (Obayashi, Y., Isobe, T., Subramanian, A., Suzuki, S. \& Tanabe, S. Ed.) pp. 317-322. By TERRAPUB.

Hyde, K.D. (1989) Ecology of tropical marine fungi. Hydrobiologia, 178, 199-208.

Kappe, R., Fauser, C., Okeke, C.N. and Maiwald, M. (1996) Universal fungus-specific primer systems and group-specific hybridization oligonucleotides for 18S rRNA. Mycoses, 39, 25-30.

Kim, S.H., Uzunovic, A. and Breuil, C. (1999) Rapid detection of Ophiostoma piceae and $O$. quercus in stained wood by PCR. Appl. Environ. Microbiol. 65, 287-90.

Leahy, J.G. and Colwell, R.R. (1990) Microbial degradation of hydrocarbons in the environment. Microbial Rev. 54(3), 427 - 450. 
Lee, S.B. and Taylor, J.W. (1990) Isolation of DNA from fungal mycelia and single spores PCR protocols in blood. In: "PCR Protocols: A Guide to Methods Applications" (Innis, M.A.; Gefand, D.H.; Sninsky, J.J. \& White, T.J., Ed.) pp. 2827. San Diego: Academic Press.

Lewin, B. (1990) “Genes IV”. pp. 497-517. Cambridge: Cell Press.

Michalcewicz, W. (1995) Effect of diesel fuel for diesel engines on the numbers of bacteria, fungi and biomass of soil microorganisms. Rocz. Pzh. 46, 91-97.

Okerentugba, P.O. and Ezeronye, O.U. (2003) Petroleum degrading potentials of single and mixed microbial cultures isolated from rivers and refinery effluent in Nigeria. Afr. J. Biotechnol. 2(9), $288-292$.

Parsons, T.R., Matia, Y. and Lalli, C.M. (1984) Determination of petroleum hydrocarbons. "A Manual of Chemical and Biological Method For Sea Water Analysis”. pp. 56-59, Pergamon Press, Oxford.

Raghukumar, C., Shailaja, M.S., Parameswaran, P.S. and Singh, S.K. (2006) Removal of polycyclic aromatic hydrocarbons from aqueous media by the marine fungus NIOCC\# 312: involvement of lignin-degrading enzymes and exopolysaccharides. Indian J. Mar. Sci. 35(4), 373-379.

Reynolds, E.S. (1963) The use of lead citrate high $\mathrm{pH}$ as an electron opaque stain in electron microscopy. J. Cell. Biology, 17, 208-212.

Saitou, N. and Nei, M. (1987) The neighbor-joining method: A new method for reconstructing phylogenetic trees. Mol. Biol. Evol. 4(4), 406-425.

Sandhu, G.S., Kline, B.C., Stockman, L. and Roberts,G.D. (1995) Molecular probes for diagnosis of fungal infections. J. Clin. Microbiol. 33, 2913-19.

Santos, E.O., Rosa, C.F.C., Passos, C.T., Sanzo, A.V.L., Burkert, J.F.M., Kalil, S.J. and Burkert, C.A.V. (2008) Pre-screening of filamentous fungi isolated from a contaminated site in Southern Brazil for bioaugmentation purposes. Afr. J. Biotechnol. 7(9), 1314-1317.

Shin, J.H., Nolte, F.S. and Morrison, C.J. (1997) Rapid identification of Candida species in blood cultures by a clinically useful PCR method. J. Clin. Microbiol. 35, 1454-9.

Sikkema, J., De Bont, J.A.M. and Poolman, B. (1995) Mechanisms of membrane toxicity of hydrocarbons. Microbiol. Rev. 59(2), 201-222.

Witholt, B., De Smet, M.J., Kingma, J., Van Beilen, J.B., Kok, M., Lageveen, R.G. and Eggink, G. (1990) Bioconversions of aliphatic compounds by Pseudomonas oleovorans in multiphase bioreactors: Background and economic potential. Trends Biotechnol. 8, 46-52.

Yagafarova, G.G., Gataullina, E.M., Barakhnina, V.B., Yagafarov, I.R. and Safarov, A.Kh. (2001) A new oil-oxidizing micromycete Fusarium sp. Prikl. Biokhim. Mikrobiol. 37, 77-79.

Egypt. J. Microbiol. 45 (2010) 
Zhou, G., Whong, W. Z., Ong, T. and Chen, B. (2000) Development of a fungusspecific PCR assay for detecting low-level fungi in an indoor environment. Mol. Cell. Probe.14, 339-348.

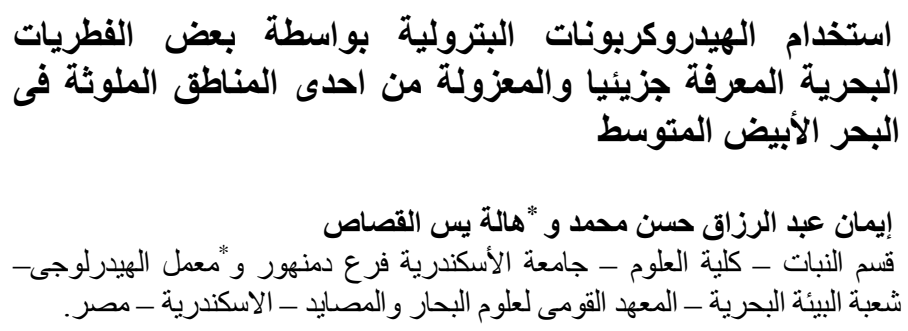

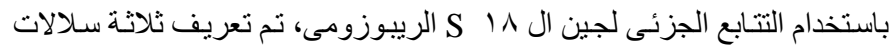

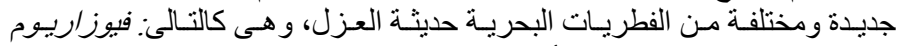

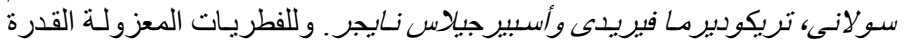

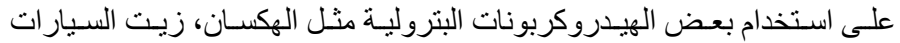

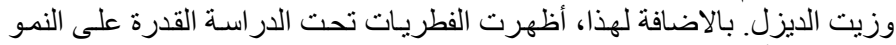

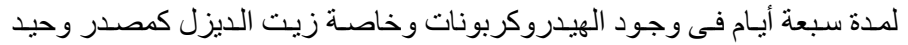

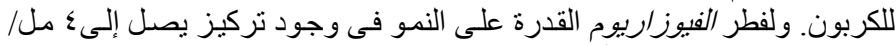

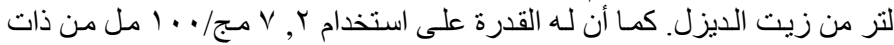

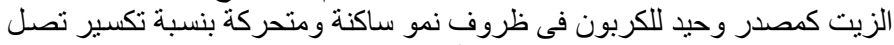

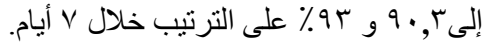

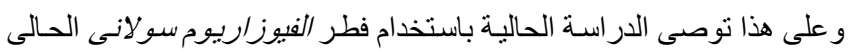
فى التخلص من الهيدروكربونات البترولية التى قد تتسرب إلى لتى مياة البحار. 